\title{
KONTRIBUSI PEMIKIRAN IMAM SYATHIBI DAN ABRAHAM H. MASLOW TENTANG KEBUTUHAN DASAR MANUSIA
}

\author{
Yusuf Yahya \\ Email: yusuf.yahya8686@gmail.com
}

\begin{abstract}
The five basic needs of human to formulate the laws and regulations related to protectionof one's religion, his soul, hisself, his offspring, his goods and his mind, as it was recognized by Syatibi's theory called alMasalihadh-Dharuriyyah (basic protected human needs) have been enhanced by Abraham H. Maslow. Every one of humans after being protected by the law, he should be capable of enhancing such five principles . When one's religionwas protected from intimidation and violence, protected to do all the given orders and to leave all the given prohibitions in his religion as what Syatibi asserted, thus, at the same time the human should need his five basic needs called physiological needs to be fulfilled, such as need of air or oxygen to breath, need for foods and water, sexual desire, and having break, etc. Again, all these basic needsmust be fulfilled. Otherwise if they do not happen, one's belief should get a trouble, and his convenience would be threatened for his own obedience of his belief or of his religion. That is because he would convert to get busier in order to fulfill his own basic needs. When one could feel safe on the first level, he would rise to the upper level where his self and his soul are protected under safe and convenience as it was intended by Syatibi. Maslow also means that a person on this gratification level needs to be safe (safety need). A person is given a ptotection of the law to care himself and his soul from murder, intimidation as well as violence. Hence, that is what intended by Maslow: a human must have a safe sense including safe in his neighborhood, his family and hisself.
\end{abstract}

\begin{abstract}
ABSTRAK
Terdapat lima kebutuhan dasar manusia untuk membentuk hukum dan peraturan yang berkaitan dengan perlindungan agama seorang, jiwa dan dirinya, keturunannya, harta serta akalnya, sebagaimana yang diperkenalkan dalam teori Imam Syatibi yang disebut dengan teori al-Mas \}a $>$ lih $\}$ ad>-D>aru>riyyah(kebutuhan dasar manusia yang dilindungi) yang kemudian dikembangkan oleh Abraham H. Maslow. Setiap orang yang dilindungi oleh hukum pada waktu yang sama ia akan mampu meningkatkan ke lima prinsip dasar tersebut. Di saat agama seseorang dilindungi dari intimidasi, gangguan, paksaan maupun kekerasan, maka ia juga dilindungi untuk melakukan segala perintah dan menjauhi segala larangan yang ditetapkan dalam agamanya sebagaimana dinyatakan oleh Imam Syatibi. Oleh karena itu, pada waktu bersamaan manusia tentunya akan membutuhkan kebutuhan lima yang pokok yang disebut dengan kebutuhan jasmani yang harus dipenuhi seperti kebutuhan terhadap udara atau oksigen untuk bernafas, kebutuhan terhadap makanan dan minuman, naluri seksual, beristirahat, dan sebagainya. Sekali lagi, semua kebutuhan dasar ini wajib dipenuhi. Sebaliknya jika itu tidak terjadi, maka kepercayaan atau keyakinan seorang akan mendapatkan masalah/kesulitan dan keyakinannya tersebut bisa menjadi terancam dalam hal ketaatannya terhadap keyakinan dan agamanya. Hal tersebut menyebabkan subyek atau penganut agama tertentu akan beralih kepada suatu kesibukan yang lebih dalam rangka pemenuhan kebutuhan dasarnya. Di saat seorang merasa aman pada tingkatan pertama, ia dengan sendirinya akan naik ke tingkat yang lebih tinggi di mana diri dan jiwanya akan terlindungi di bawah naungan rasa aman dan kenyamanan, sebagaimana yang dimaksudkan oleh Imam Syatibi. Maslow juga mengimplikasikan bahwa seorang di atas tingkat gratifikasi butuh terhadap rasa aman (kebutuhan rasa aman). Seorang diberikan perlindungan hukum untuk menjaga diri dan jiwanya dari pembunuhan, intimidasi, dan begitu juga dari kekerasan. Demikianlah yang dimaksudkan oleh Maslow bahwa manusia harus memiliki rasa aman, termasuk keamanan dalam lingkingan, keluarga dan dirimya.
\end{abstract}

Kata Kunci: Pemikiran, Imam Syatibi-Abraham H. Maslow, Kebutuhan Dasar Manusia

Jurnal Al Mashaadir, Vol. 1, No.2,2020 


\section{A. Pendahuluan}

Sebagai manusia yang diciptakan Allah s.w.t., makhluk mulia ini diberikan otoritas tertinggi untuk menjadi khalifah sebagai pengganti penguasa di bumi. Manusia diciptakan sebagai ah\}sanu taqwi>m, makhluk yang sempurna dalam pembentukannya. Semua makhluk ciptaan selain manusia itu sendiri tunduk untuk memenuhi kebutuhan manusia. Alam, oksigen, air, lingkungan yang sehat, udara yang segar, makanan sehat, minuman sehat, rumah, yang semua ini merupakan kebutuhan manusia, dan inilah yang disebut oleh Maslow sebagai basic needs atau basic human physical needs. Semua kebutuhan tersebut pada satu level saling berkesinambungan untuk memenuhi kebutuhan manusia dan bila salah satu unsur tidak terpenuhi, maka individu yang bersangkutan mengalami deprivasi, suatu kehilangan kebutuhan dasarnya yang menyebabkan individu bersangkutan bisa kehilangan kendali atas perilakunya sendiri dikarenakan seluruh kapasitas manusia tersebut dikerahkan dan dipusatkan hanya untuk kebutuhan dasarnya itu. Hal ini bisa terjadi bila individu bersangkutan mengalami extreme hunger, kelaparan yang sangat. Begitu juga dalam pandangan Syathibi, yang menurut beliau dari segi eksistensi atau kebutuhan nyata yang harus dipenuhi oleh individu manusia berupa makanan, minuman, pakaian, tempat tinggal dan lain sebagainya yang merupakan kebutuhan pokok, di mana beliau mengkategorikannya sebagai maqasid daruriyya t(primary needs) yang harus dipenuhi (Maslow, 153-342: 2006).

Dengan terpenuhinya kebutuhan di atas, maka seseorang dapat melanjutkan untuk memenuhi kebutuhannya di level yang lebih tinggi. Manusia pada selanjutnya membutuhkan kebutuhan akan rasa aman, kebutuhan untuk mencintai dan dicintai, kebutuhan untuk dihargai dan kebutuhan untuk aktualisasi diri. Inilah pendapat Abraham H. Maslow dalam Hierarchy of Needs-nya (Maslow, 17-23: 1954).

Begitu juga menurut Syathibi, ketika daruriyyah terpenuhi, maka manusia bisa menaiki untuk memenuhi kebutuhan dasar berikutnya yang disebut maslahah hajjiyyah (complementary needs). Hanya saja Syathibi dalam tingkatan kedua ini lebih cenderung kepada skop ibadah, kebiasaan (custom), hubungan sosial (mu'amalah) dan jinayah (crime or public law) (Syatibi, 21: 2010)

Ke lima hirarkhi kebutuhan dasar baik yang berasal dari kontribusi Abraham H. Maslow maupun kontribusi Syatibi mempunyai fungsi yang sama terhadap kebutuhan dasar manusia, atau keduanya 
saling melengkapi. Di satu sisi, ketika manusia memenuhi physiological needs atau kebutuhan dasar jasmani, maka manusia bersamaan membutuhkan sesuatu termasuk peraturan yang dapat menjaga agama dan akidahnya. Ketika manusia naik ke tingkat yang lebih atas dalam Safety needs, kebutuhan akan rasa aman, maka pada waktu bersamaan individu yang bersangkutan membutuhkan untuk memelihara dan menjaga jiwa dan raganya, seperti yang diusung Syathibi.

Dengan demikian, penelitian ini ingin menganalisis lebih lanjut pokokpokok pikiran yang disumbangkan oleh ke dua tokoh dalam pemenuhan kebutuhan dasar manusia.

\section{B. Metodologi}

Penelitian ini adalah penelitian kualitatif menggunakan analisa konten mengkaji pokok-pokok pemikiran Imam Syathibi dan Abraham H. Maslow. Contentanalysis sangat cocok digunakan dalam penelitian ini karena datanya berupa informasi tertulis dan tercetak. Pendekatan analisa komparasi Imam Syathibi dengan konsep dan teori maslahat Abraham H. Maslow.

\section{Hasil dan Pembahasan}

\section{Kontribusi Pemikiran Imam Syathibi Tentang Kebutuhan Dasar Manusia}

Nama lengkap Syathibi adalah Abu Ishq Ibrahim bin Musa bin Muhammad alLakha'i asy-Syatibi. Kelahiran beliau belum diketahui, tetapi diperkirakan lahir pada $720 \mathrm{H}$. Beliau wafat pada tanggal 8 Sya'ban $790 \mathrm{H}$ atau tahun $1388 \mathrm{M}$ di Granada. Beliau berdomisili di Al-Andalus dengan firkah Sunni bermazhab Maliki. Beliau hidup pada masa Spanyol Islam, berasal dari kota Xativa yang kemudian dikenal dengan Imam dari Xativa. Sedangkan keluarganya merupakan imigranketurunan bangsa Arab-Yaman dari Banu Lakhm yang berasal dari Betlehem, Asy-Syam.Granada merupakan sebuah kerajaan Islam yang berada di bawah pemerintahan Daulah Umawiyah yang mengikuti aturan-aturan Andalusia Selatan (Ali, 23: 1998).

Syathibi telah berusaha melakukan semacam penyempurnaan dan bahkan pembaharuan. Beliau menulis sebuah kitab tentang metodologi Hukum Islam yang relatif tebal dan mendalam (empat jilid), sementara Kitab al-Muwafaqat yang disusun oleh Syaikh Bakr bin'Abdillah Abu Zaid terdiri dari 6 jilid. Sisitematika yang digunakan relatif baru yang berupaya mengaitkan kepastian hukum dengan keadilan hukum (al'adalah) sebagai tujuan 
hukum dalam syariah yang lazim diistilahkan dengan maqasid al-syari'ah (tujuan syariat) secara lebih erat dan sungguh-sungguh. Pembahasan ini beliau jadikan sebagai sebuah topik baru yang berdiri sendiri di dalam studi metodologi hukum Islam, karena sebelumnya topik tentang maqasid asy-syariah tidak menjadi perhatian yang besar. Jikapun diuraikan, selalu dikaitkan atau dibahas bersamaan dengan methode lain. Shathibi berupaya mengupayakan kepastian hukum dan keadilan hukum secara lebih sistematis dan komprehensif, yang dia sebut dengan maqashid as-syari'ah (al-Yasa', 45: 2016). Beliau menjadikan pembahasan tentang kepastian hukum dan keadilan hukum yang dikemas menjadi maqashid asy-syari'ah sebagai bagian penting bahkan lebih penting daripada metodologi Hukum Islam dan menjadikan kesanggupan memahami dan menemukan kepastian hukum dan keadilan hukum sebagai salah satu syarat utama untuk kebolehan melakukan ijtihad (istinbat) (Zulfahmi, 12: 2016).

Seluruh umat dan bangsa, menurut Syathibi, bahkan semua agama sepakat bahwa syari'ah diletakkan dan diciptakan untuk memelihara lima urgensi yang vital, yaitu: agama, jiwa, keturunan, harta dan akal (rasio). Mengetahui lima dasar tersebut bagi suatu umat/bangsa sangat urgent, meskipun menurut Syathibi belum ada penetapan dalil tertentu mengenai struktur ilmu ini, dan juga belum adanya asal tertentu sebagai referensi, tetapi dapat diketahui kesesuaiannya dengan syariah melalui kompilasi dalil yang tak terbatas pada satu bab (Syatibi, 31:2010). Meskipun syariah yang bertujuan untuk memelihara dfaruriyya tyang lima (five principles of need) bersandar kepada sesuatu yang ditentukan, maka penentuannya secara adat adalah wajib, dan juga ahli ijma' supaya merifer kepada sesuatu yang ditentukan tersebut (Syatibi, 31: 2010).

Bahkan Syathibi menyebutkan d\{aruriyyat (lima pokok) merupakan satu circle dengan hajiyyat (secunder)dan tahsiniyyat (complementary), yang kesemuanya disebut beliau sebagai kulliyat asy-syari'ah atau sebagai referensi dasar dalam masalah ushul al-fiqh (Syatibi, 19 :2010). Daruriyyat dalam ushul al-figh menurut Syathibi sesuatu yang harus dilakukan dengan tujuan menegakkan masalih atau kebaikan agama dan dunia, yaitu apabila hal tersebut hilang maka masalih atau kebaikan dunia tidak berjalan secara konsisten dan berkelanjutan tetapi akan terjadi kerusakan dan tirani (kacau balau). Daruriyyat, seperti disebutkan ada lima, yaitu: menjaga agama, jiwa, keturunan, harta dan akal. Sedangkan 
hajiyyat merupakan sesuatu yang sekunder atau sesuatu yang dibutuhkan seperti pemberian keleluasaan dan mengangkat/ mengeliminasi dari kesempitan, seperti pemberian rukhsah, pembolehan dalam berburu, menikmati segala sesuatu yang baik dari segala hal yang halal. Selanjutnya adalah tahsiniyyat, yang berarti mengambil sesuatu yang layak dari kebiasaan-kebiasaan yang baik, menjauhi keadaan yang membawa 'aib atau pencemaran yang dipandang rendah oleh akal yang dominan/unggul (dalam mencerna dan memilih antara 2 sisi: kebaikan atau yang lebih baik, begitu juga kebaikan atau keburukan). Syathibi di bagian ketiga ini mengeksamplikasi penghilangan najis, menutup 'aurat dan memakai perhiasan (Syatibi, 20 :2010).

Dalam bagian daruriyyat, menurut Syathibi, untuk memeliharanya diperlukan dua unsur:

a. Menegakkan rukun atau elemen krusial serta menetapkan kaedahkaedahnya, dan hal tersebut merupakan ekspresi/ungkapan untuk memelihara daruriyyat dari segi eksistensi (Syatibi, 18: 2010). Memelihara daruriyyat dari sisi eksistensi diaplikasikan melalui penegakan/implementasi dan penetapan. Sedangkan kebalikannya dari segi non- eksistensi diimplementasikan dengan meninggalkan sesuatu yang harusnya ditinggalkan, seperti Jinayat atau Hukum Publik. Dengan demikian maka tidak dapat diasumsikan bahwa konservasi daruriyyat/hal-hal yang pokok dari segi eksistensi seperti salat dan memakan sesuatu yang layak dimakan, merupakan konservasi dari segi non-eksistensi juga, karena dengan melakukan segala hal ini yang merupakan eksistensi dan suatu ketetapan tidak dinafikan menjadi suatu permulaan atau tidak muncul non eksistensi terhadapnya secara tibatiba. Dengan demikian, konservasi daruriyyat dari sisi eksistensi bukan merupakan pemeliharaan dari segi non-eksistensi dengan arti ini (Syatibi, 18: 2010). Maka ketika salat diwajibkan, ia merupakan rukun yang eksis bagi seorang Muslim karena merupakan kewajiban absolut. Sedangkan penerapannya karena tidak dirinci dalam Alquran, maka hukum eksistensi tidak berlaku. Dengan demikian hukum non eksistensi sebagai penjabar, penjelas untuk melengkapi implementasi rukun salat dapat dilakukan. Termasuk juga hukum positif dapat berlaku 
sebagai alat yang menjembatani kevakuman hukum karena belakangan setelah hukum eksistensi datang, tidak diperkuat, tidak diperjelas oleh hukum setelahnya (ius constitutum).

b. Adanya pencegahan terhadap kecacatan yang terjadi atau mungkin terjadi pada daruriyyat, dan ini ungkapan tentang pemeliharaan/konservasi dari sisi non-eksistensi (Syatibi, 18:2010) emeliharaan di sini dimaksudkan bukan hanya penjagaan itu sendiri, tetapi juga berarti penegakan hukum, penciptaan lapangan kerja, pertumbuhan pembangunan, di mana kebutuhan atau urgensi pokok mendesak kepada pelaksanaannya untuk maslahat umum dan fasilitas/ kepentingan negara, seperti juga untuk mencapai pertumbuhan. Maka tujuan dari maqashid syari'ah di sini bukan hanya pemeliharaan dalam bentuk penjagaan itu saja, tapi lebih jauh untuk menciptakan pembangunan dan pertumbuhan untuk segenap fasilitas kehidupan dan kemaslahatan umum (public interest) juga kemaslahatan pribadi (personal interest). Dalam hal ini juga berarti terwujudnya kelapangan dan keleluasaan sehingga tercegah dari stagnansi suatu negara ataupun statis dalam peradaban (Syatibi, 18: 2010). Di sini dimaksudkan bahwa untuk melestarikan pokok pertama; daruriyyat atau primary needs, maka diperlukan pemeliharaan dari yang awalnya tidak ada, kemudian diberdayakan menjadi ada. Dalam hal ini, sebagaimana contoh di atas bahwa untuk melakukan hal ini dibutuhkan pembangunan masif dan pertumbuhan di segala bidang untuk kehidupan bangsa dan negara. Hal ini sebagaimana juga termaktub dalam pasal 33 UUD 1945 bahwa Negara menjamin kesejahteraan rakyatnya. Penegakan hukum dan pemberdayaan manusia menjadi penting untuk merealisasikan kepentingan individu sebagai person, anggota masyarakat, dan rakyat suatu Negara. Dengan demikian Negara mengalami kemajuan dan dengan sendirinya juga menghindari dari stagnansi ataupun peradaban statis.

Syathibi menambahkan, bahwa asal ibadah harus merifer kepada pemeliharaan terhadap agama dari segi eksistensi, seperti iman, pengucapan dua 
kalimat syahadat, salat, zakat, puasa, haji dan sebagainya. Sedangkan adat atau kebiasaan merifer kepada pemeliharaan jiwa dan akal dari segi eksistensi juga, seperti makan makanan, minum, pakaian, tempat tinggal, dan sebagainya. Mu'amalat (social relation) merifer kepada pemeliharaan keturunan dan harta dari segi eksistensi, sampai kepada menjaga jiwa dan akal juga, tetapi dengan perantaraan dan korelasi adat/kebiasaan lokal. Begitu juga Jinayat/hukum pidana yang meliputi perintah terhadap kebaikan dan larangan dari perbuatan mungkar, merifer kepada pemeliharan terhadap keseluruhan dari segi hukum noneksistensi.

Ibadat dan adat telah digambarkan sebelumnya, sedangkan mua'malat merifer kepada kemaslahan manusia antar individu, seperti pemindahan kepemilikan dengan barang tukar (seperti jual beli, salam, mudarabah) atau tanpa pertukaran barang (seperti: hibah, wakaf), pemindahan kepemilikan dengan akad terhadap hamba sahaya, manfaat atau barang. Jinayat merifer kepada seperti apa yang disebutkan sebelumnya dengan pembatalan (invaliditas), maka disyariatkan di dalamnya sesuatu yang dapat mencegah pembatalan (tidak berlakunya suatu hukum). Salah satu methode adalah dengan memperbaiki seluruh kemaslahatan, seperti qisas dan diyat untuk jiwa (pembunuhan), hadd (hukuman) untuk sesuatu yang merusak akal, seperti minuman keras dan konsumsi narkotik, pemberian jaminan terhadap nilai harta, jaminan untuk menjaga keturunan seperti pencegahan dari zina,jaminan rasa aman dari perampokan atau pembegalan serta pemberian jaminan untuk harta, dan sebagainya.

Dengan hukum non-eksistensi, maka hukum positif dapat diberlakukan untuk memfungsikan maqasid syari'ah. Dalam hukum Islam disebut Jinayat. Jinayat di sini berfungsi untuk menentukan hukum dan peraturan yang berlaku pada suatu masyarakat dalam implementasi perlindungan terhadap agama, sehingga mengeliminasi jauhnya tauhid pada seorang warga negara, menjauhi dari penistaan agama, termasuk juga dalam point ini harus adanya toleransi antar agama, serta tidak adanya pemaksaan pemilihan kepada suatu agama. Hukum juga dapat mengatur untuk melindungi warga suatu Negara dari perusakan akal dan pikiran. Di Indonesia, selain pelarangan penyebaran minuman keras, meskipun tidak eksplisit terhadap konsumsi minuman keras yang hanya lebih merifer kepada peraturan daerah sebagai pelaksana peraturan dalam korelasinya dengan kearifan dan budaya 
lokal, terdapat juga Undang-Undang anti Narkoba. Untuk melindungi jiwa, Negara membentuk hukum atas tindakan (onrechtmatigedad) pembunuhan berencana, pembegalan, pemerkosaan, intimidasi dan sebagainya. Di ruang lingkup pemeliharaan terhadap harta, Negara membentuk Undang-Undang tentang pembegalan, perampokan, hukum pidana tentang pencurian, dan sebagainya. Dalam melindungi keturunan, qanun di Aceh diberi otoritas yang besar untuk menghapus khalwat, perzinaan, dan sebagainya.

Dari paragraf di atas jelaslah bahwa kontribusi Imam Syathibi lebih cenderung kepada kebutuhan dasar manusia yang lima (Five principles of Human Need Protection)untuk dilindungi. Sehingga Imam Syathibi lebih cenderung kepada penerapan hukum untuk terpeliharanya atau menjaga ke lima dasar kebutuhan manusia tersebut. Hal tersebut dikarenakan Imam Syathibi dikenal dalam sejarah teori hukum Islam sebagai teoritis besar yang meletakkan basis teoretis dan kerangka kerja bagi ahli hukum untuk secara jeli dan cerdas dapat menangani hukum-hukum substantif agar hukumhukum tersebut otoritatif dan dapat beradaptasi dengan perubahan kondisi sosial (Rofii, $16: t t$ ).
Hal tersebut senada dengan Roscou Pound yang memberikan peluang living law di masyarakat atas kebaikan dan maslahah yang membawa kepada dinamika dan perubahan masyarakat itu sendiri. Di sini, menurut Roscou Pound, adanya pemberian peluang dan andil untuk menentukan hukum yang berlaku pada anggota masyarakat sesuai dengan kearifan dan kemampuan lokal serta adat yang konstan bagi kehidupan sosial mereka. Roscou Pound juga berpendapat bahwa hukum harus dilihat atau dipandang sebagai suatu lembaga kemasyarakatan yang berfungsi untuk memenuhi kebutuhan-kebutuhan sosial (human wants), dan tugas dari ilmu hukum adalah untuk memperkembangkan suatu kerangka dengan mana kebutuhankebutuhan sosial dapat terpenuhi secara maksimal (Soekanto, 17: 2012). Paham ini dapat dilihat dari pendapatnya:

The record of a continually wider recognising and satisfying of human wants or claims or desires through social control; a more embracing and more effective security of social interest; a continually more complete and effective elimination of waste and precluding of friction in human enjoyment of the goods of existence- in short, a continually more efficacious social engineering. (Roscou Pound, 47:1959 \& Roscoe Pound, 99: 1930). 
Maksudnya adalah: "Kumpulan peraturan atau hukum yang mengenal lebih luas secara berkelanjutan dan memuaskan kebutuhan manusia, hak atau kemauan melalui pengendalian sosial; keamanan yang lebih aplikatif, diterima, dan lebih efektif terhadap kepentingan sosial; penghapusan yang lebih global (mujmal) dan lebih efektif terhadap penghamburan dan pencegahan gesekan/percekcokan dalam kenikmatan hidup manusia dari harta yang didapatkan, singkat kata, alat rekayasa sosial yang lebih efektif secara berkesinambungan."

Di sini Roscou Pound memberi penekanan kepada pemeliharaan/ perlindungan syari'ah (God's intention) yang merupakan azas maslahah, yaitu: pemeliharaan agama, jiwa, akal, keturunan dan harta. Ke lima tujuan ini merupakan cikal bakal teori Roscou Pound yang menekankan living law untuk merealisasikan maqasid syariah sebagai dimensi maslahah dalam kehidupan bermasyarakat. Persamaan antara keduanya terletak bahwa unsur pemeliharaan maslahah haruslah sistematis. Pemeliharaan terhadap satu unsur yang lebih dikedepankan harus diprioritaskan. Namun, Roscue Pound menyatakan semuanya dilakukan secara berkesinambungan, atau merupakan satu kesatuan yang keseluruhannya wajib dipelihara. Hanya saja Roscue Pound tidak begitu menekankan kepada 5 kebutuhan dasar Syatibi, khususnya agama. Roscue Pound lebih bertitik kepada pemeliharaan harta di mana yang lainnya juga merupakan suatu kebulatan yang sama (human wants, human claims or desires).

Ruh At-tasyri'menampilkan cita-cita maslahat sebagai tujuan (Asmawi, 3: tt). Memasukkan pertimbangan maslahat sebagai kerangka acuan di dalam merumuskan dan memecahkan suatu persoalan hukum adalah keniscayaan baik secara teologis maupun sosiologis. Merealisasikan maqasid syari'ahsebagai dimensi maslahah dalam kehidupan bermasyarakat senada dengan defenisi maslahah yang dikuatkan oleh Al-Buthi ((Al-Buthi, 58: 1982) ) yaitu:

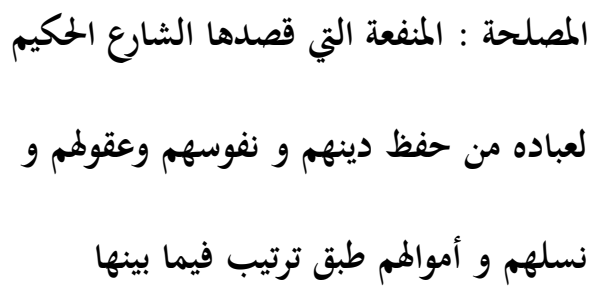

Maksudnya adalah: "Maslahat adalah manfaat yang dikehendaki atau ditetapkan Syari yang Maha Bijaksana untuk para hamba-Nya yang meliputi pemeliharaan agama, jiwa, akal, keturunan, harta mereka sesuai dengan urutannya." 
Dilihatdaritermanya, maslahat dari segi etimologis berasal dari kata Bahasa Arab, yaitu: صلح - صلح , yang berarti kebaikan. Kata al-maslahah adalah bentuk tunggal (mufrad), sedangkan jamaknya adalah al-masalih(المصالحح) yang menunjukkan makna bahwa maslahat merupakan sesuatu yang banyak kebaikan dan manfaatnya. Di samping itu, maslahat juga dapat diartikan dengan suatu perbuatan yang mendatangkan kebaikan atau manfaat (Zulkarnain, 2: 2016). Maslahat memiliki dua pengertian: pertama, hakiki, yaitu maslahat sama dengan manfaat, baik dari segi lafal maupun maknanya. Kedua, majazi (metaforis), yaitu maslahat berarti suatu perbuatan yang mendatangkan kebaikan atau maslahat (Husein, 5 :1991). Imam AlGhazali mendefenisikan maslahat dengan al-muhafazah 'ala maqas\}id asy-syar'yang meliputi perlindungan terhadap agama, jiwa, akal, keturunan dan harta (AlGhazali, 25l: 1971).

Ada beberapa kriteria dan batasan maslahat, sebagaimana yang disimpulkan oleh Said Ramadhan al-Buthi, antara lain adalah:

Maslahat dalam syari'at Islam tidak terbatas pada kehidupan duniawi saja akan tetapi juga mencakup kehidupan akhirat. Dalam istilah singkatnya disebut sebagai maslahat yang berwawasan dunia akhirat. Kaitan maslahat dengan dua orientasi dunia dan akhirat ini merupakan sesuatu yang mesti dalam syari'at Islam. 'Izzuddin mengatakan bahwa kemaslahatan itu untuk dunia dan akhirat. Apabila kemaslahatan itu hilang, maka rusaklah urusan dunia akhirat. Apabila kerusakan muncul hancurlah penghuninya (Izz al-Din,3: 2009).

Senada dengan itu, Syathibi mengatakan bahwa kemaslahatan harus diwujudkan, sebaliknya kerusakan mesti dihapuskan menurut syara', yang kemudian harus diarahkan kepada tegaknya kehidupan dunia akhirat (Syathibi, 37 : 2010).

a. Maslahat yang dikandung syariat Islam tidak hanya terbatas pada sisi dan norma material semata, tetapi juga norma spiritual agar maslahat tersebut bisa memenuhi kebutuhan jasmani dan rohani. Sebagian filosof menentang adanya maslahat rohani yang bersifat spiritual karena maslahat rohani menurut pandangan mereka akan terwujud dengan sendirinya jika kebutuhan jasmani terpenuhi.

Maslahat yang ditetapkan syari'ah harus menjadi pijakan bagi maslahat lainnya. Semua maslahat harus mengacu pada norma agama yang telah digariskan Alqur'an dan Hadis. Bukan maslahah yang 
selama ini dipahami oleh orang yang beranggapan hanya dijadikan sebagai hujjah (dalil agama) yang berdiri sendiri dan tidak terikat dengan Alqur'an dan Hadis, dengan menjadikan akal sebagai satu-satunya patokan dalam menilai maslahat. Standarisasi nilai maslahat kepada akal semata akan membatalkan syari'at sebagaimana ditegaskan oleh Syathibi: "Salah besar kalau akal punya otoritas melebihi nas yang berkonsekuensi syariat boleh dibatalkan oleh akal." (Syathibi, 85-88: 2010).

Berdasarkan hal di atas, apa yang disebut dengan maslahat perlu diberi batasan sehingga keberadaan maslahat tidak dijadikan sebagai satu tempat berlindung untuk bisa melegalisasi permasalahan-permasalahan yang sebenarnya tidak masuk dalam kategori maslahat. Untuk itu, al-Buthi telah menetapkan beberapa persyaratan, yaitu:

a. Maslahat tidak boleh bertentangan dengan maqasid asy-syari'ah.

b. Maslahat tidak bertentangan dengan nash Alqur'an.

c. Maslahat tidak bertentangan dengan hadis Nabi.

d. Maslahat tidak bertentangan dengan qiyas.

e. Maslahat tidak bertentangan dengan maslahat lainnya yang lebih penting atau maslahat yang setara dengannya (al-Buthi, 118: 1982).
Ada yang mengatakan bahwa teori maslahah lahir dari Imam Al-Ghazali. Ada juga yang mengatakan teori maslahah berasal dari gurunya, Imam Al-Juwaini. Kemudian mengalami puncak pengembangan theori tersebut oleh Imam al-Syathibi. Teori ini mengalami kemandegan panjang seiring dengan stagnansi ilmiah dunia Islam pada umumnya. Muhammad 'Abduh dan Rasyid Ridha di Mesir, juga al-Maududi di India, merekomendasikan agar muridmurid mereka mengkaji Al-Muwafaqat fi Ushul-Al-Ahkam, buah pena al-Syathibi yang mengaplikasikan teori liberal ini. Melalui 'Abduh dan Ridha, beberapa orang pembaharu putera Indonesia berusaha memperkenalkan gagasan besar ini di pertengahan abad XX. Sayangnya, program ini dilakukan secara dangkal, di samping umat ketika itu belum siap untuk menerima penafsiran yang dipandang jauh dari nash. Di sisi lain, maslahah dipandang sebagai doktrin juga sebagai methode pengembangan nilai dan ruh hukum Islam ke dalam perubahan sosial (Yudian, 44-45 :2007).

Maslahah merupakan entitas dari Al-Maqashid asy-Syar'iyyah yang tujuannya mencapai dan menjamin serta melestarikan maslahat itu sendiri bagi umat manusia, khususnya umat Islam. Menurut Prof. Yudian Wahyudi, maslahah sebagai 
entitas dari Al-Maqashid asy-Syar'iyah merupakan metode di mana pendekatan ini telah dilakukan Umar bin Khattab yang tampil begitu kontraversial, tetapi percaya diri sekalugus jenius. Umar sangat praktis, fleksibel dan humanis dalam memecahkan masalah-masalah hukum yang terjadi di masyarakat (Yudian, 44-45: 2007).

Makin jelas bahwa Imam Syathibi menekankan kepada proteksi lima pokok (Five principles of Human Need Protection) bagi kehidupan manusia: perlindungan terhadap agama, sehingga terhindar dari riddah bagi pemeluk Muslim. Dalam keterangan kitab al- Muwafaqat yang telah ditahqiq, perlindungan terhadap agama ini berlaku universal. Sehingga setiap Negara memberikan toleransi terhadap pluralisme agama, yang juga merupakan hasil interpretasi ayat "lakum dinukum waliya din". Dalam Undang-undang yang berlaku di Indonesia juga memberikan kebebasan dalam beragama dan berkeyakinan. Kedua, perlindungan terhadap jiwa, sehingga jiwa seorang terlindungi dengan adanya hukum yang efektif yang memberikan hukuman berat kepada pelaku pembunuhan, intimidasi, kekerasan, termasuk kekerasan dalam rumah tangga, terorisme, dan human traficking. Ditinjau dari segi maslahat, maka termasuk dalam point ini adalah pelarangan merokok di tempat publik, karena menimbulkan mafsadah (kerusakan jiwa, lingkungan, udara) bagi pelaku (active smoker) juga bagi orang di sekitarnya (passive smoker). Ketiga, pemeliharaan keturunan, di mana hukum diberlakukan dalam rangka pemeliharaan keturunan seseorang. Dalam fungsinya juga, seorang anak terpelihara statusnya dari akibat hukum ilegal orang tuanya. Dengan demikian Negara memberikan perlindungan atas korban pemerkosaan, korban kekerasan dalam rumah tangga, kekerasan sexual (sexual bully, human traficking (Maslow, 153-342 :2006), perbuatan asusila, dan sebagainya. Negara juga menjamin bahwa dalam satu keluarga harus mempunyai garis keturunan legal. Jika terjadi lahirnya anak di luar pernikahan yang sah, maka hal tersebut dapat berimplikasi buruk bagi status anak dan pada akhirnya menjadikan akibat hukum yang negatif bagi si anak, yang juga berdampak kestabilan emosi anak tidak seimbang ketika beranjak dewasa. Maka ketika terganggu stabilitas emosional dan untuk terjaganya keseimbangan psikologis seorang anak ketika dewasa, maka berikutnya akan dilihat teori Maslow bahwa manusia mempunyai sifat untuk dihargai dan menjaga harga diri/ kehormatannya sendiri (self esteem) yang akan dibahas pada sub-bab berikutnya. Pada tahap berikutnya; pemeliharaan 
harta, menurut Syatibi, harus juga dilindungi. Dalam hal ini, Negara mengancam dengan varian hukuman kepada pencuri, perampok, maling, pembegal, penyamun, yang dalam hal ini juga adalah perlindungan harta Negara dari koruptor, yang mana Indonesia juga telah mengeluarkan Undang-undang antikorupsi dan dibentuknya Komisi Pemberantasan Korupsi. Pada segi koruptor, Negara memberikan hukuman khusus. Tak heran dalam penjagaan harta Negara, Syahrur berijtihad untuk memberikan hukuman potong tangan dan kaki secara silang ('ala khilaf) dengan menganologikannya sebagai muharib dan qati at-tariq. Terakhir, bahwa Negara menjamin untuk memberikan perlindungan akal. Beberapa produk hukum seperti Undang-undang anti Narkoba, Undang-undang tentang larangan minuman keras, Undang-undang pembatasan alkohol, dan sebagainya merupakan manifestasi andil Negara untuk memerangi mafsadah atas akal/pikiran manusia. Dengan kata lain, Negara menjamin terpeliharanya maslahat atas dasar perlindungan akal/pikiran manusia, baik sebagai individu maupun sebagai anggota masyarakat.

Dengan demikian, Syatibi menampilkan ke lima dasar urgent di atas dengan prospek hukum yang diberlakukan pada suatu Negara yang dapat menimbukan kesadaran permanen terhadap hukum. Syatibi menginginkan Negara mengeluarkan Undang-undang atau peraturan dengan tujuan terjaganya ke lima dasar kebutuhan manusia yang pada kodratnya harus dilindungi. Dalam makna ini, Syatibi secara zahir/ tampak berkontribusi dalam memenuhi kebutuhan manusia terhadap perlindungan hukum dari berbagai aspek, setelah terpenuhinya secara natural kebutuhan dasar yang ditawarkan Maslow, seperti pada sub-bab berikut ini.

2. Kontribusi Pemikiran Abraham H. Maslow tentang Kebutuhan Dasar Manusia (Telaah dan Komparasi)

Abraham Maslow lahir di Brooklyn, New York, 1 April 1908 dan meninggal di California pada tanggal 8 Juni 1970, atau bersamaan dengan usianya 62 tahun. Beliau adalah teoritikus yang banyak memberi inspirasi dalam teori kepribadian. Ia juga seorang psikolog yang berasal dari Amerika dan menjadi seorang pelopor aliran psikologi humanistik.

Kebutuhan dasar menurut Maslow berpatokan kepada istilah Dynamics of the Need Hierarchy (Dinamika Hirerkhi Kebutuhan). Abraham Maslow menggunakan piramida sebagai peraga untuk memvisualisasi gagasannya mengenai teori hierarkhi kebutuhan. 
Menurut Maslow, manusia termotivasi untuk memenuhi kebutuhan-kebutuhan hidupnya (AlleyDog.com, 2017), Abraham Maslow menggunakan istilah atau terma instinctoid dalam merifer kepada terma kebutuhan pokok manusia. Di sini Abraham Maslow bermaksud membedakan kebutuhan dasar phisikal manusia untuk menyelamatkan manusia itu sendiri. Beliau lebih menekankan kepada kebutuhan dasar atas tingkah laku dan karakter. Kebutuhan instinctoid ini juga merupakan kebutuhan pokok manusia seperti makanan, air, dan tempat perlindungan/ tempat tinggal. Namun, di luar kebutuhan pokok ini, menurut Maslow, manusia membutuhkan kebutuhan rohani, seperti cinta, sifat menerima, memiki dan dihargai, yang semuanya penting untuk menjadi seorang yang seimbang dengan baik dan menjadi orang yang bermanfaat secara sempurna (AlleyDog.com, 2017).

Teori Abraham Maslow yang terkenal dengan Hierarchy of Needs, menyatakan bahwa manusia memiliki kebutuhan tertentu yang harus dipenuhi untuk kebutuhan hidup yang sehat. Kebutuhan ini memotivasi kita untuk bertindak sesuai dengan cara yang kita lakukan, dan khususnya dengan cara yang memuaskan kebutuhan yang belum terpenuhi. Di samping itu, Abraham Maslow menyarankan kebutuhan dasar ini tidak dalam kategori penting atau urgent sejajar, tetapi ia berada dalam suatu hierarkhi atau urutan (terbentuk seperti pyramid). Dengan kebutuhan yang paling penting diutamakan, yang disusul kemudian kebutuhan pokok berada di posisi bawah (Maslow, 153-342: 2006).

Hierarkhi kebutuhan dasar manusia sering dipresentasikan sebagai sebuah pyramid. Pembentukan dasar merupakan kebutuhan fisiologis yang esensial untuk bertahan dalam kehidupan dan menuju rasa aman. Ini termasuk kebutuhan untuk oksigen, air dan makanan, sebagaimana yang disebutkan di atas. Hanya ini saja yang merupakan kebutuhan dasar manusia di saat kebutuhan-kebutuhan ini yang berlevel lebih rendah ditemukan terhadap beberapa tingkatan di mana seorang bisa berpindah ke jenjang yang lebih tinggi untuk memenuhi kebutuhan yang lain. Kebutuhan ini dinamakan juga kebutuhan dasar (basic needs) yang jika tidak dipenuhi dalam keadaan yang sangat ekstrem (misalnya kelaparan) bisa menyebabkan manusia yang bersangkutan kehilangan kendali atas perilakunya sendiri karena seluruh kapasitas manusia tersebut dikerahkan dan dipusatkan hanya untuk kebutuhan dasarnya itu (Syatibi, 17-19 :2010)

Dalam pandangan Syathibi, kebiasaan yang dilakukan manusia untuk 
melindungi jiwa dari segi eksistensi, atau sesuatu yang tampak sebagai kebutuhan dasar manusia yang bersangkutan, seperti makan, minum, pakaian, tempat tinggal, dan lain sebagainya, yang kesemuanya merupakan maqashid daruriyyah haruslah dipenuhi (Maslow, 153-342 :2006). Jika semua kebutuhan pada tingkat pertama dalam perlindungan jiwa dan diri seseorang terpenuhi, maka peringkat kedua dalam melindungi akal juga akan membuka ruang untuk dilindungi. Sebagaimana Maslow mengatakan bahwa jika kebutuhan dasar (basic needs) ini relatif sudah tercukupi, muncullah kebutuhan yang lebih tinggi, yaitu kebutuhan akan rasa aman (AlleyDog.com, 2017).

Level kedua terdiri dari kebutuhan terhadap keselamatan dan rasa aman (Safety and Securuty Needs), yang termasuk di dalamnya kebutuhan menemukan stabilitas dan sebuah lingkungan di mana seorang merasa aman dari kejahatan dan kerusakan. Ini juga dapat berarti mencari pekerjaan tetap dan layak, memiliki sebuah rumah dalam lingkungan yang aman, atau memiliki uang di bank (AlleyDog.com, 2017. Dalam pendapat Syathibi, mu'amalah dan hubungan manusia merifer kepada penjagaan keturunan dan harta dari segi eksistensi dan keniscayaan. Artinya manusia mempunyai hak dan kekuasaan (bevoegheid) untuk memiliki rasa aman dalam menjaga keselamatan keturunan dan harta. Hal ini dapat terbentuk dengan adanya jinayah, sehingga terbentuk dalam hukum positif yang imperatif bagi rakyat suatu Negara (Syatibi, 19-20 :2010). Jenis kebutuhan inilah yang menurut Maslow merupakan jenis kebutuhan kedua yang berhubungan dengan jaminan keamanan, stabilitas, perlindungan, struktur, keteraturan, situasi yang bisa diperkirakan, bebas dari rasa takut, cemas dan sebagainya. Karena dengan kebutuhan inilah maka manusia membuat peraturan, Undang-Undang, mengembangkan kepercayaan, membuat sistem, asuransi, pensiun dan sebagainya (W. Sarwono, 174-178:2002).

Sama halnya dengan basic needs, kalau safety needs ini terlalu lama dan terlalu banyak tidak terpenuhi, maka pandangan seseorang tentang dunianya bisa terpengaruh dan pada gilirannya pun perilakunya akan cenderung ke arah yang makin negatif (W. Sarwono, 174-178 :2002).

Tingkatan ketiga,menurut Maslow, merifer kepada kebutuhan rasa cinta dan rasa memiliki, dan ini juga berarti memiliki rekan/partner ataupun pasangan, teman, keluarga, group dalam ibadah (AlleyDog.com, 2017), ataupun link /jaringan yang mendukung sehingga 
tercipta kekerabatan dan keluarga yang familiar. Dalam pandangan Syatibi, perlu adanya pemeliharaan keturunan (hifzu annasl) yang menimbulkan rasa cinta antar anggota keluarga, sehingga keturunan mempunyai urgensi untuk dijaga. Dengan demikian juga dapat mengantarkan kepada rasa cinta dan kekerabatan familiar dengan sanak saudara, teman, rekan, organisasi dan jaringan kemasyarakatan lainnya.

Kebutuhan keempat mencakup kebutuhan terhadap pemeliharaan kehormatan, yang ini juga dipegang oleh Syathibi dengan hifzu an-nasl, tetapi hifzu an nasl pada Syathibi lebih difungsikan untuk menjaga kehormatan individu sosial dari perbuatan zina yang dapat berakibat kaburnya garis keturunan dan mengganggu jalur kewarisan dan wasiat melalui jalur ayah. Tetapi Maslow dalam pemeliharaan harga diri (Esteem Needs) seorang baik dalam personalitas maupun anggota masyarakat membutuhkan untuk dikenal (recognition) dalam anggota masyarakat, dihormati (respect), dihargai martabat dan kedudukannya (dignity), kepercayaan dan keyakinan (confidence) serta hak dasar meraih prestasi dan penghargaan (sense of achievement) (AlleyDog.com, 2017).Menurut Maslow, level ini juga termasuk di dalamnya penyelesaian tingkat studi di universitas, kelulusan dalam test kandidat praktisi hukum dalam jurisdiksi (sistem hukum) tertentu atau kemajuan yang diraih seorang dalam karirnya.

Level terakhir atau level kelima adalah kebutuhan manusia untuk mengaktualisasikan dirinya (SelfActualization), yaitu kebutuhan yang terus berkelanjutan untuk memenuhi potensial seorang dan untuk menjadi orang yang terbaik sebisa mungkin (AlleyDog.com, 2017) di tingkat aktualisasi diri, seorang yang mengaktualisasikan dirinya, atau terus berproses menuju kesuksesan, cenderung untuk memiliki lebih banyak "puncak pengalaman" daripada orang yang tidak melakukannya. Puncak pengalaman, di mana istilah Maslow menggunakan "Peak Experiences", yang berarti juga bahwa seorang tidak berhenti pada satu pengalaman, maka ketika ia jatuh atau gagal, membuatnya terbuka untuk membuka peluang lain dengan pengalaman lainnya. Dalam arti kata, ia terus melakukan uji joba dari sesuatu yang didapatkan secara konstan atau berkelanjutan sampai kepada puncak kesuksesan karena ia mempunyai kemauan keras untuk aktualisasi dirinya.

Puncak pengalaman merifer kepada titik yang tinggi dalam kehidupan seorang, saat-saat adanya kegirangan yang sangat, euphoria, cinta atau rasa terpesona, di mana hal ini semuanya 
mendefenisikan saat-saat di mana seorang merasakan segalanya, benar-benar merasa hidup dan dalam keharmonisan yang sempurna dengan alam ( ${ }^{A}$ lleyDog.com, 2017). Sementara Syatibi, dalam kedudukan kebutuhan daruri, yaitu menjaga akal, sehingga diperlukan Undang-Undang atau peraturan yang mengatur kelestarian akal dan menghilangkan segala sesuatu yang merusak akal. Tetapi Maslow memaksudkan peningkatan kualitas akal yang diberdayakan dalam aktualisasi diri. Ide yang masih eksis dalam benak atau otak seseorang tertuang dan diterapkan dalam kreativitas dan aktivitas positif yang mengantarkan pelakunya kepada kesuksesan yang nyata. Ketika ia merasakan kegagalan, maka ia menggunakan akal atau ide untuk prestasi yang lebih gemilang. Pada tahap ini, seorang berada pada puncak kesuksesan atas ide cemerlang yang dibangun. Dengan demikian, kelestarian akal yang instan berkembang dengan aktualisasi diri konstan dari ide atau pikiran seorang. Sebagai dasar, teori Syatibi atas dasar pemeliharaan akal dikembangkan dengan aktualisasi diri sebagaimana teori Maslow.

Menurut Maslow, meta kebutuhan untuk mengaktualisasikan diri terdiri dari: kebenaran, kebaikan, keindahan atau kecantikan, keseluruhan (kesatuan), dikotomi-transedensi, berkehidupan (berproses, berubah tetapi tetap pada esensinya), keunikan, kesempurnaan, keniscayaan, penyelesaian, keadilan, keteraturan, kesederhanaan, kekayaan (banyak variasi, majemuk, tidak ada yang tersembunyi, semua sama penting), tanpa susah payah (santai, tidak tegang), bermain (fun, rekreasi, humor), dan mencukupi dirisendiri (id.m.wikipedia.org 2017).

Dari uraian di atas, dapat disimpulkan 5 (lima) hierarkhi kebutuhan manusia, yaitu:

a. Kebutuhan fisiologis atau dasar

b. Kebutuhan akan rasa aman

c. Kebutuhan untuk dicintai dan disayangi

d. Kebutuhan untuk dihargai

e. Kebutuhan untuk aktualisasi diri Maslow menyebut empat kebutuhan mulai dari kebutuhan fisiologis sampai kebutuhan harga diri dengan sebutan homeostatis, kemudian berhenti dengan sendirinya (Boeree, 277-290:2006) Maslow memperluas cakupan prinsip homeostatik ini kepada kebutuhan-kebutuhan tadi, seperti rasa aman, cinta dan harga diri yang biasanya tidak kita kaitkan dengan prinsip tersebut (Boeree, 277-290 :2006). Maslow menganggap kebutuhan-kebutuhan defisit tadi sebagai kebutuhan untuk bertahan cinta dan kasih sayang pun sebenarnya memperjelas kebutuhan ini sudah ada 
sejak lahir persis sama dengan insting (instinctoid) (Boeree, 277-290:2006).

Lebih jauh menurut Maslow, kebutuhan dasar manusia disusun ke dalam hierarkhi atau urutan pra-potensi relatif. Satu implikasi utama dari pengutaraan kalimat ini adalah bahwa gratifikasi ${ }^{1}$ (tingkat kepuasan) menjadi konsep penting sebagai rasa kehilangan (penerimaan jika satu kebutuhan hilang) pada theory motivasi, karena ia melepaskan organism (individual) dari donimasi kebutuhan psikologi yang lebih banyak secara relatif, yang dengan demikian mengizinkan pula timbulnya tujuan-tujuan sosial lainnya yang lebih banyak. Kebutuhan psikologi sepanjang dengan tujuannya yang parsial, di saat pemberhentian yang telah digratifikasi secara kronik (berkesinambungan) untuk eksis sebagai penentu efektif atau pembentuk karakter (Maslow, 17-18 :1954). Sekarang kebutuhan psikologi muncul hanya pada cara dan kebiasaan dalam pengertian bahwa kebutuhan itu muncul sekali lagi untuk mendominasi organisme (makhluk) jika kebutuhan itu dihalangi. Tetapi tingkah laku hanya terbentuk dengan kebutuhan yang tak terpuaskan. Apabila rasa lapar telah dipuaskan, ia menjadi sesuatu yang tidak penting dalam dinamika seorang untuk sekarang ini (Maslow, 17-18 :1954). Maslow memaksudkan bahwa seorang akan berubah karakternya apabila kebutuhan psikologi tak terpenuhi. Hal ini jelas berbeda ketika seorang merasa aman dan nyaman pada sebuah gratifikasi kebutuhan. Di sisi lain, Maslow menginginkan teori gratifikasi ini menjadi keseimbangan yang menghindari manusia dari dominasi kebutuhan psikologi yang relatif lebih banyak untuk diraih. Seperti ingin dicintai, ingin dihargai, ingin berada di puncak kesuksesan, dan sebagainya.

Pernyataan ini, menurut Maslow sedikit dikualifikasi atau disyaratkan dengan sebuah hipothesis untuk didiskusikan lebih lengkap nantinya, yakni, di mana hal tersebut pada kenyataannya individual-individual tersebut pada suatu kebutuhan tertentu pada orang yang telah dipuaskan, yakni; individu-individu yang terbaik dilengkapi/ disempurnakan untuk menerima kehilangan terhadap kebutuhan tersebut di masa akan datang, dan bahwa lebih jauh, kata Maslow, orang-orang yang kekurangan atau kehilangan pada masa lalu akan bereaksi dengan beda untuk memperbaharui kepuasan dari seorang yang tak pernah merasa kehilangan (Maslow, 17-18:1954).

Di sini Maslow ingin memaksudkan bahwa ketika seorang dicabut kenikmatannya pada masa lalu, maka potensinya untuk merubah kebutuhan yang telah hilang pada masa 
lalu untuk menjadikannya lebih semangat dalam meraih kebutuhan psikologi seperti kesuksesan, akan lebih cenderung besar semangatnya dibandingkan dengan orang yang tidak pernah merasa kehilangan.

Abraham W. Maslow juga menyatakan juga bahwa anugerah, nikmat yang kita terima merupakan hak kita dari Sang Khaliq (taken for granted). Selaku hamba sudah mempunyai hak untuk menerima segala kenikmatan yang diberikan Allah s.w.t. Begitu juga sebaliknya, karunia yang diberikan terkadang juga dilupakan oleh hamba penerima. Dalam hal ini Maslow menambahkan juga bahwa terkadang seorang yang menerima karunia atau kenikmatan (blessing), kadang kala terhenti kesadaran mereka ketika hidup di dalam kenikmatan itu sendiri, sebaliknya jika karunia itu hilang atau diambil darinya, maka sudah tak bernilai lagi nikmat itu, karena berhenti fungsinya untuk dimanfaatkan.

Abraham mencontohkannya dengan karakteristik kultur Amerika bahwa kemajuan dan peningkatan yang tak diragukan lagi yang telah diperjuangkan dan telah diraih sepanjang 150 tahun merupakan suatu gerakan cepat yang dilakukan oleh orang yang ceroboh dan dangkal ilmunya, dan dapat dikatakan bahwa kesemuanya merupakan kepalsuan, begitu juga sebagai sesuatu yang tak ada nilainya, sebagai sesuatu yang tak pantas dari perjuangan, atau perlindungan, atau penilaian, dan itu hanya karena masyarakatnya belum menjadi masyarakat yang sempurna (Maslow, 17-18:1954).

Lebih lanjut Abraham mengatakan, bahwa perjuangan sekarang atas nama kebebasan kaum wanita akan menjadi satu contoh untuk mengilustrasikan kompleksitas ini tetapi merupakan sesuatu yang penting, dan ditujukan untuk menunjukkan seberapa banyak orang cenderung untuk berpikir mengenai cara yang berbeda/dikotomi (dichotomous), cara yang lebih terpisahkan dari cara hierarkhi dan integratif. Pada umumnya dapat dikatakan bahwa hari ini di budaya Amerika, menurut Maslow, bahwa impian seorang wanita, yang merupakan impian di mana ia tidak bisa melihatnya dengan nyata, lebih sering tentang seorang lakilaki yang akan jatuh cinta kepadanya dengan memberikan sebuah rumah, dan juga dapat memberikan seorang anak (baby). Dalam dunia fantasi seorang wanita, yang dengan demikian ia dapat hidup bahagia seterusnya. Namun, kenyataannya ialah bahwa tidak menjadi masalah seberapa besar seorang yang merindukan sebuah rumah dan merindukan seorang bayi, ataupun merindukan orang yang mencintainya, yang cepat atau lambat seorang akan menjadi "kenyang" ${ }^{2}$ atau "puas" dengan 
karunia ini, akan mengantarkan mereka kepada sesuatu yang layak mereka terima, dan ia akan mulai merasa resah dan merasa tidak puas jika ada sesuatu yang kurang, atau jika ada sesuatu yang lebih pantas untuk dicapai. Dengan demikian, kesalahan yang sering terjadi adalah menentukan rumah, bayi dan seorang suami sebagai sesuatu yang merupakan kepalsuan, atau bahkan mungkin merupakan sebuah jebakan perbudakan, dan kemudian merindukan kebutuhan yang lebih tinggi dan gratifikasi yang lebih tinggi dalam satu cara atau dua cara dalam pilihan sekalipun, seperti kerja professional, mendapatkan kebebasan untuk melakukan perjalanan, otonomi personal atau untuk sesuatu yang disukai.

Maslow menyadari bahwa manusia ketika tidak mendapatkan satu level kepuasan kebutuhan yang ingin dicapai, maka potensi psikologinya tidak seimbang, dan tidak sejajar pada satu gratifikasi. Akibatnya, subyek bersangkutan akan cenderung mengeluh, resah, tidak compliant atau tidak rela, tidak ikhlas, tidak puas atau tidak qana'ah, putus asa dan sibuk dengan keresahan akan kehilangan suatu kebutuhan. Padahal, menurut Maslow, jika pada satu titik gratifikasi tidak terpuaskan oleh subyek, pada hakekatnya akan mengantarkan dia lebih anthusias atau lebih semangat untuk meraih gratifikasi di masa akan datang.
Maslow mengajarkan agar seorang tidak berhenti pada satu titik (pada kondisi safe zone), tetapi harus lebih cenderung mempunyai keinginan besar untuk naik di tingkat yang lebih tinggi. Dengan kata lain, mausia seharusnya tidak berhenti untuk mengaktualisasikan dirinya pada satu tingkatan, tetapi harus lebih jauh berada pada tingkat yang lebih tinggi. Meskipun demikian, ketika seorang terjatuh pada satu titik gratifikasi, seharusnya tidak resah dan tidak berhenti hanya karena kegagalan.

Selain itu,pokok utama dari Grumble Theory (teori karena mengeluh kepada sesuatu) dan teori kebutuhan hierarkhi-integratif , adalah bahwa ketidakdewasaan dan ketidakbijaksanaan akan muncul ketika seorang memikirkan semua kebutuhan yang diungkapkan di atas, dianggap alternatif eksklusif yang saling melengkapi. Hal terbaik untuk memikirkan tentang seorang perempuan yang tidak merasa puas dengan harapan yang sangat besar untuk menggantungkan kepada segala sesuatu, yang mana ia miliki, dan kemudian seperti seorang dari kalangan serikat buruh yang meminta sesuatu yang lebih. Dapat juga dikatakan bahwa perempuan tersebut biasanya akan menjaga segala keberkahan nikmat yang ia dapatkan serta akan memiliki kebutuhan tambahan yang lain dari keberkahan nikmat yang ia miliki. Tetapi meskipun 
sebagaimana tertulis di sini seperti jika kita belum belajar pelajaran abadi ini, di mana ketika apa saja yang ia (perempuan) berhasrat untuk sebuah karir atau sesuatu yang lain, tatkala hal tersebut diraih maka semua proses akan mengulangi dengan sendirinya. Setelah kurun waktu kebahagiaan, hasrat, dan terpenuhinya kebutuhan menjadi kebutuhan yang tak terelakkan didapatkan sebagaimana mestinya (taken for granted), dan menjadi sesuatu yang resah dan belum terpuaskan lagi untuk sesuatu yang lebih. Sekali lagi, Maslow menginginkan kedewasaan dan kematangan bersikap dalam suatu kebutuhan yang belum terlengkapi dengan kebutuhan di atasnya. Pada prinsipnya, semua titik gratifikasi atau level kebutuhan mempunyai pengaruh berkesinambungan dan saling melengkapi satu sama lain.

Meskipun demikian, Maslow sepertinya tidak mau terjebak dengan teori kebutuhan yang ia usung. Maslow, sebagaimana disebutkan di atas, lebih merifer kepada kebutuhan rohani dan kepuasaan batin. Dibandingkan teori kebutuhan yang diusung oleh Syathibi, karena Syathibi lebih cenderung kepada cara bagaimana hak seorang terlindungi dalam menjaga dan memelihara stabilitas lima dasar pokok sehingga manusia dapat hidup tenteram, dan ini juga sebagaimana diusung oleh Maslow bahwa manusia pada kodratnya memiliki kebutuhan natural untuk mendapatkan rasa aman dan rumah yang nyaman (bukan mewah).

Pada titik yang sama, Maslow dan Syathibi menginginkan hukum yang diciptakan dan atas dasar kebutuhan natural dan kebutuhan sekondari dapat terbentuk bersamaan, di mana ketika seorang mendapatkan harta sebagai taken for granted, maka pada waktu yang sama ia juga ingin merasa aman dengan terjaganya harta tersebut (safe and security sense). Begitu juga dalam pemeliharaan akal, Syathibi menguatkan penerapannya dengan dibentuk h\}ad (hukuman) bagi peminum khamar misalnya, termasuk yang ia inginkan penghilangan atau pemberantasan obat-obat terlarang dan narkotik (al-mukhaddirat), sehingga ada preventive action dan pemberian efek jera dengan hukum yang dibentuk pada suatu Negara.

Dalam hal ini, Maslow lebih mempertajam kemaslahatan yang dibangun Syathibi. Maslow menginginkan bahwa dengan akal manusia secara natural memiliki kebutuhan dasar mengayomi pendidikan dan pengajaran, bukan hanya pemeliharaan akal itu sendiri tetapi akal digalakkan potensinya. Akal ingin dikembangkan sehingga terwujud aktualisasi diri (self actualization) dengan menampilkan sosok yang elegan, 
berprestasi (achievement) dan pada intinya, manusia memiliki puncak pengalaman (peak experience) dengan berada pada puncak kesuksesan.

Meskipun demikian, sebagaimana dicontohkan oleh Maslow, Maslow tidak ingin seorang terjebak dengan teorinya serta merta, sehingga ketika seorang berada pada level pencapaian kebutuhan tertentu, tidak ingin melanjutkan ke level berikutnya.

Di sisi lain, Maslow sebenarnya ingin memberikan nuansa rasa puas (contented sense), yang dalam tasawuf Islam dikenal dengan qana'ah, sehingga beliau berhati-hati bila mana seorang terus mengeluh, resah, dan terus merasa tidak cukup dengan keanugerahan dan keberkahan yang telah didapatkan. Dengan kata lain, manusia bergerak maju memenuhi kebutuhan yang lebih atas dan tidak diam pada zona aman (safe zone), dan juga menjadikannya seimbang dengan tidak ada rasa resah, keputusasaan, keluhan, dan perasaan negatif (negative sense) lainnya ketika berada pada level kebutuhan tertentu.

Lebih jauh lagi Maslow menambahkan bahwa pada masanya terdapat banyak problema timbulnya kelemahan umat manusia: kesedihan, ketamakan, eksploitasi, prasangka (suuz zhan), kehinaan, perasaan kecut/takut, kebodohan, kecemburuan, dan egoisme/mementingkan diri sendiri.

Ini semuanya merupakan penyakit yang dimiliki manusia. Menurut Maslow, kita dapat menyembuhkan penyakit ini apabila kita mengatur/memanajnya sekali dalam satu waktu. Psiko-analisis, contohnya adalah sebuah therapy dalam yang khusus, yang dapat mengatur problema-problema ini, dengan diberikannya waktu yang cukup, kemampuan keuangan yang cukup, dan kemampuan/skill yang cukup.

Dalam hal agama, dinyatakan bahwa kebanyakan orang kehilangan atau melupakan secara subjektif pengalaman keagamaan, dan menentukan/ mendefenisikan kembali agama sebagai satu kompilasi kebiasaan, tingkah laku, dogma, bentuk, di mana pada saat ekstrim menjadi legalistik, birokratis, (Cantril, 278-298 : 1955), konvensional, kosong dan menjadi makna yang paling benar pada satu kata, anti-keagamaan.

Pengalaman mistik, penerangan, kebangkitan yang besar, melalui orang yang melihat secara kharismatik yang memulai segala sesuatu, dilupakan, hilang, ditransformasi ke dalam rival mereka. Suatu agama yang terorganisasi, seperti gereja, pada akhirnya bisa menjadi musuh besar dari pengalaman keagamaan dan pelaku pengalaman keagamaan itu sendiri (Kamus Bahasa Indonesia, 206-207: 2008). 
Di sini terlihat bahwa agama harus dipisahkan dari kepentingan agama itu sendiri. Agama yang ingin dikembangkan Maslow sebagaimana ditanggapi oleh editor buku beliau Religions, Values, and Peak-Experiences, berisi kebiasaan yang patut dilakukan, norma, tingkah laku, dogma, aspek agama. Di mana ketika disikapi secara ekstrim, agama hanya menjelma legalistik, alat untuk mengatur tata kehidupan masyrakat dan mu'amalah atau hubungan sosial.

Di sisi lain, dengan nuansa ekstrim, agama dijadikan alat birokratis. Dengan demikian, setelah agama dijadikan mindset, dogma dan tingkah laku, maka agama pada tingkat lebih tinggi mempunyai peranan dalam birokrasi pemerintahan dan menjadi hukum pada suatu negara atau wilayah dan agama menjadi konvensional. Pada saat yang ekstrim, tokoh agama kharismatik, pelaku ritual keagamaan pada suatu agama, organisasi agama yang bangkit dilupakan dan kadang pula dianggap rival.

\section{Kesimpulan}

Dari uraian di atas, pada akhirnya ada beberapa hal yang dapat disimpulkan, antara lain adalah:

a. Lima kebutuhan dasar manusia untuk terbentuknya hukum dan peraturan yang mengatur terpeliharanya agama, jiwa, keturunan, harta dan akal manusia, sebagaimana teori yang dikenalkan Syatibi sebagai maslahah daruriyyah (basic protected human needs), dikembangkan oleh Maslow bahwa setiap manusia setelah dilindungi oleh hukum, manusia mempunyai potensi untuk mengembangkan ke lima dasar tersebut.

b. Di saat manusia dilindungi agamanya, dilindungi dari penistaan, dilindungi untuk melaksanakan segala perintah dan menjauhi segala larangan dalam agamanya, meningkatkan kualitas agamanya, meningkatkan kualitas iman dan taqwa sebagai hamba, sebagaimana yang dimaksudkan oleh Syatibi, maka pada saat bersamaanmanusia membutuhkan kebutuhan dasarnya (Phisiological Needs) untuk dipenuhi, seperti kebutuhan udara dan oksigen untuk bernafas, makanan, air, kebutuhan biologis, istirahat, dan sebagainya.

c. Semua kebutuhan dasar ini haruslah dipenuhi. Jika tidak, maka akan terganggu agama seorang, terancam kenyamanannya dalam taat terhadap agama, karena ia disibukkan memenuhi kebutuhan dasarnya. Ketika seorang sudah aman pada 
tingkatan pertama, maka ia akan naik ke tingkatan berikutnya di mana ia akan dilindungi jiwanya, sebagaimana yang dimaksudkan Syatibi. Begitu juga menurut Maslow, pada tingkat gratifikasi ini, seorang membutuhkan rasa aman (Safety Need). Ia diberikan perlindungan oleh hukum untuk menjaga diri dan jiwanya dari pembunuhan, intimidasi dan kekerasan.

d. Demikian juga yang diinginkan oleh Maslow, bahwa manusia harus mempunyai rasa aman termasuk keamanan dalam lingkungan, keluarga dan dirinya. Maslow juga menekankan pada tahap ini manusia supaya mendapatkan pekerjaan yang layak. Hal yang paling penting pada tingkatan ini bahwa manusia membutuhkan jaminan keamanan, stabilitas, dependency (kebebasan), perlindungan, struktur, keteraturan, hukum, situasi yang bisa diperkirakan, bebas dari rasa takut, cemas, kekerasaan atau chaos dan sebagainya.

e. Pada tahap selanjutnya, maka menurut Syatibi dibutuhkannya perlindungan atas keturunan supaya timbulnya keluarga yang sakinah, penuh dengan mawaddah atau cinta. Begitu juga menurut Maslow, pada tingkatan ini beliau sebut sebagai the belongingness and love needs, di mana manusia membutuhkan rasa cinta, rasa memiliki, dan rasa dicintai. Setiap orang ingin mempunyai hubungan yang hangat dan akrab, bahkan mesra dengan orang lain. Semuanya ini tercipta jika Negara memberikan perlindungan atas terjaganya keturunan seseorang dengan menghasilkan keluarga. Tetapi lebih jauh, Maslow memperluas kepada hubungan persahabatan, rekan dan anak/ sanak famili.

f. Pada tahap keempat, Syatibi menekankan perlunya perlindungan atas harta. Sehingga Negara menjamin terlindunginya harta yang dikuasai atau dimiliki warganya dari pencurian, perampasan, perampokan, pembegalan dan sebagainya. Jika hak ini dilindungi, atau hartanya dilindungi dengan adanya hukum, maka secara bergiliran akan timbul rasa kekuatan, penguasaan, kompetensi, percaya diri dan kemandirian, bahkan kemulian. Di Alquran pun disebutkan bahwa harta merupakan fadlun atau karunia, khairun atau kebaikan, 
kemulian yang pada akhirnya mengantarkan manusia terpenuhi kebutuhan harga diri (the Esteem Needs), sebagaimana yang dimaksud oleh Maslow dalam hierarchy of needs-nya. Pada tahap ini, ada bagian kedua, yang disebut sebagai keinginan untuk sebuah reputasi dan prestige/martabat, di mana manusia juga membutuhkan penghargaan dan dihormati oleh orang lain, status, ketenaran, kejayaan, dominasi, rasa ingin dikenal, kebanggaan, rasa membutuhkan perhatian orang lain, sesuatu yang dianggap penting dan apresiasi dari orang lain. Begitu juga dengan harta, seorang akan merasa dihargai dan dihormati di kalangannya atau di masyarakatnya.

g. Pada tahap akhir, sebagaimana Syatibi ingin adanya hukum dan peraturan untuk terpeliharanya akal dan pikiran manusia, seperti dengan dibentuknya Undangundang anti Narkoba, pembatasan minuman keras/alkohol untuk diperdagangkan, dan sebagainya. Oleh karena itu, Maslow menginginkan agar akal/ide seorang yang dilindungi oleh hukum itu, diaktualisasikan berupa ide-ide yang cemerlang, seperti kontribusi dalam penelitian ilmiah. Pada tahap ini, yang juga merupakan teori Kurt Goldstein (1930), di mana manusia mempunyai kecenderungan untuk mengaktualisasi diri mereka sesuai dengan potensi yang mereka miliki. Kecenderungan ini dapat dikatakan sebagai kemauan kuat untuk menjadi lebih dari orang lain, di mana ia mampu untuk melakukan hal tersebut. Maslow mencontohkan level ini kepada penguatan potensi di masingmasing profesi, seperti kreasi menciptakan musik bagi pemusik, seniman membuat lukisan, penyair harus menulis syairnya.

h. Maslow menambahkan bahwa manusia bisa dan mereka harus bisa. Mereka harus megetahui bakat alami mereka. Inilah yang disebut dengan aktualisasi diri. Semua ini dilakukan jika Negara menjamin kebebasan berfikir, kebebasan mengeluarkan ide, yang ditransformasikan ke dalam aktivitas dan kreativitas, sebagaimana yang dinyatakan Syatibi berkenaan dengan perlindungan akal dan ide yang kemudian diaktualisasikan dalam kreasi, penemuan ataupun seni, 
i. Hal esensial dalam tulisan ini juga adalah bahwa 5 (lima) kebutuhan dasar manusia atau yang disebut alMasalih al-Khamsah yang ditawarkan Syathibi lebih menggunakan pendekatan hukum dan kebutuhan masyarakat terhadap hukum, sedangkan lima kebutuhan dasar yang disebut Dynamic of the Need Hierarchy yang diusung Abraham H. Maslow lebih memprioritaskan pendekatan psikologi dan kebutuhan psikologi manusia.

\section{E. Daftar Pustaka}

, On Dominace, Self Esteem, and Self Actualization, Ann Kaplan: Maurice Basset, 2006. Religions, Values, and PeakExperiences, Penguin Books, 1964. , Toward a Psychology of Being, edisi II, New York: D. Van Nostrad, 1968.

Abdurrahman, Zulkarnain, Kriteria Maslahat dalam Penetapan Hukum Islam, Pascasarjana Universitas Islam Negeri Ar-Raniry, Banda Aceh, 2016.

Abu al-'Ila, Musthafa, Kairo: Maktabah AlJundi, 1971.

Abubakar, Al-Yasa', Metode Istislahiah: Pemanfaatan Ilmu Pengetahuan dalam Ushul Fiqh, Cetakan I, Edisi I, Jakarta: Prenadamedia Group, 2016.

Ali, Adam, Abdurrahman, Al-Imam AsySyatibi 'aqidatuhu wa mauqifuhu min albida' wa ahliha, Riyadh: Maktabah ar-Rusyd, Cet. I, 1998.
AlleyDog.com, Hierarchy of Needs, diakses pada tanggal 9 Februari 2017.

Asmawi, Teori Maslahat dan Relevansinyan dengan Perundangundangan Pidana Khusus di Indonesia (belum dipublikasi).

Boeree, George, Personality Theories, Yogyakarta: Primasophie, 2006.

Buti, Ramadhan, Dawabit al-Maslahah fi at Syari'ah al-Islamiyyah, Beirut: Mu'assasatal-Risalah, 1982.

Cantril, Hadley, A Philosophy of Psychology, dalam ETC XII, dan dalam karya jurnal Maslow yang sama: Toward A Humanistic Psychology, 1955.

Ghazali, Al-Mustashfa min 'Ilm al-Ushul, dengan tahqiq Muhammad Abu al'Ila, Musthafa, Kairo: Maktabah AlJundi, 1971.

Hasan, Husain, Nazhariyah al-Maslahah fi alfigh al-Islami, Kairo: Dar al-Nahdhah al-'Arabiyyah, 1991.

Hoffman, Edward, A Biography of Abraham Maslow, Los Angeles: Jeremy P. Tarcher, 1988.

id.m.wikipedia.org : Abraham Maslow. Hierarki Kebutuhan, diakses tanggal 24 Februari 2017 pukul 05.30

id.m.wikipedia.org, diakses pada tanggal 17 Februari 2017, pukul 22.48

Maslow, Abraham, Motivation and Personality, New York: Harper and Row Publishers, Edisi Ketiga, 1954.

Nur, Zulfahmi, Kepastian, Kemanfaatan dan Keadilan Hukum (Paradigma antara Filosof Hukum Barat versus Filosof Hukum Islam), Program Pasca Sarjana Universitas Islam Negeri Ar-Raniry Banda Aceh, 2016 (belum dipublikasikan).

Pound, Roscue, An Introduction to the Philosophy of Law, New Haven: Yale University Press, 1959.

Rofii, Ahmad, Kepastian Epistemologis Hukum Islam: Kritik al-Syat\{ibi terhadap KonsepQat'i-Zanni, IAIN Syekh Nurjati, Cirebon. 
Salam, 'Izz al-Din, Qawa'id al-Ahkam fi Masalih al-An'am.

Sarwono, Sarlito, Berkenalan dengan Aliranaliran dan Tokoh-tokoh Psikologi, Jakarta: Bulan Bintang, 2002.

Soekanto, Soerjono, Pokok-pokok Sosiologi Hukum, Cet. 12, Jakarta: PT RajaGrafindoPersada, 2002.

Syatibi, Abu Ishaq Al-Muwafaqat, Taqdim: Bakar bin 'Abdillah Abu Zaid, Jilid I, Dar Ibni ‘Affan

Wahyudi, Yudian, Ushul Fikih versus

Hermeneutika: Membaca Islam dari Kanada dan

Amerika, Yogyakarta: awesea Press, 2007 